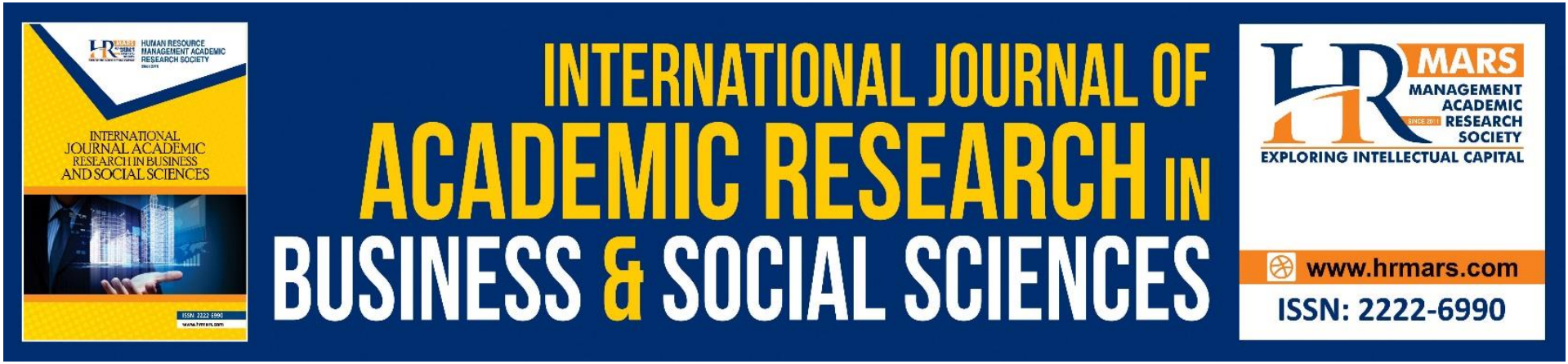

\title{
A Review on the Strategies to Enhance Graduate Employability from Higher Vocational Institutions
}

\section{Yu Jing, Arasinah Kamis, Suo Yan Mei, Ridzwan Bin Che Rus}

To Link this Article: http://dx.doi.org/10.6007/IJARBSS/v12-i1/12257

DOI:10.6007/IJARBSS/v12-i1/12257

Received: 08 November 2021, Revised: 11 December 2021, Accepted: 30 December 2021

Published Online: 19 January 2022

In-Text Citation: (Jing et al., 2022)

To Cite this Article: Jing, Y., Kamis, A., Mei, S. Y., \& Rus, R. B. C. (2022). A Review on the Strategies to Enhance Graduate Employability from Higher Vocational Institutions. International Journal of Academic Research in Business and Social Sciences, 12(1), 2621-2630.

Copyright: @ 2022 The Author(s)

Published by Human Resource Management Academic Research Society (www.hrmars.com)

This article is published under the Creative Commons Attribution (CC BY 4.0) license. Anyone may reproduce, distribute, translate and create derivative works of this article (for both commercial and non0-commercial purposes), subject to full attribution to the original publication and authors. The full terms of this license may be seen at: http://creativecommons.org/licences/by/4.0/legalcode

Vol. 12, No. 1, 2022, Pg. $2621-2630$

Full Terms \& Conditions of access and use can be found at http://hrmars.com/index.php/pages/detail/publication-ethics 


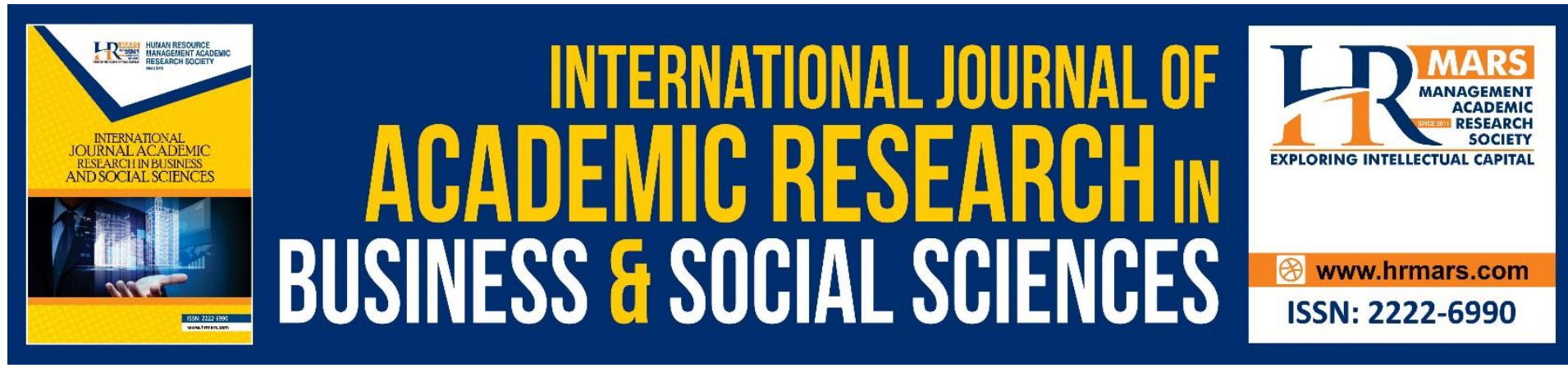

\title{
A Review on the Strategies to Enhance Graduate Employability from Higher Vocational Institutions
}

\author{
Yu Jing ${ }^{1,2}$, Arasinah Kamis ${ }^{1}$, Suo Yan $\mathrm{Mei}^{3}$, Ridzwan Bin Che \\ Rus $^{1}$
}

${ }^{1}$ Faculty of Technical and Vocational Education, Universiti Pendidikan Sultan Idris, Tanjung Malim, Perak, Malaysia, ${ }^{2}$ Ningxia Polytechnic, Yinchuan, Ningxia, China, ${ }^{3}$ Faculty of

Languages and Communication, Universiti Pendidikan Sultan Idris, Tanjung Malim, Perak, Malaysia

Corresponding Aauthor Email: fatimahsuo@fbk.upsi.edu.my

\begin{abstract}
The employability among the graduates from higher vocational institutions is an issue that is always faced by employees and discussed by many researchers. However, according to the finding of the research, researchers suggested some strategies to enhance graduate employability. This research aims to review strategies to improve employability among graduates from higher vocational institutions. The data of this study are collected from the relevant journal articles. Based on literature analysis, the authors summarized from those researches. The research makes an in-depth analysis of the current situation of Higher Vocational Students' employability and puts forward countermeasures and suggestions to improve higher vocational students' employability from the three aspects of students, schools, and enterprises. The implication of this study can help graduate to improve their employability at higher vocational institutions and to solve the employment problem of higher vocational students.
\end{abstract}

Keywords: Employability, Higher Vocational Institutions, Strategies, Graduate

\section{Introduction}

According to Khalid and his collogues (Khalid, et al., 2014) employability is presently an escalating problem among graduates all over the world. They further stated that employers have expressed many concerns over graduates lacking the relevant skills that are required of them to be employable.

Many factors cause vocational school graduates to still do not get a job after graduating. The focused factor is in terms of soft skills owned by vocational students, which is also known as employability skills ( Fitriyanto \& Pardjono, 2019). At present, the employment situation of higher vocational students in China is very serious, and there are still contradictions between the supply and demand of the total amount of labor force and talents and professional structure. Obviously, in the process of entering society and entering the workplace, the employability of higher vocational students plays a leading role in job hunting. Therefore, 
improving students' employability is an important issue that all higher vocational colleges have to face.

\section{Statement of Problem}

Based on the employment report of China Higher Vocational Students in 2020 (Blue Book of employment) issued by Macbeth college, the number of college graduates in China is reached 8.74 million in 2020, an increase of 400000 compared with 2019. Among them, the number of graduates in higher vocational education is about 3.85 million. If we take into account the number of unemployed people in previous years, this figure is expected to reach 9 million (Chinese 3-year Vocational College Graduates'Employment Annual Report, 2020) (The number of job seekers of higher vocational students has increased rapidly, coupled with the novel coronavirus pneumonia crisis, the global economic growth has slowed down, under the influence of macro factors such as the depression of market economy, the employment problem of higher vocational students is prominent.

In May 2014, the State Council issued 《The Decision of the State Council on Accelerating the Development of Modern Vocational Education. 》, clearly proposed the need to accelerate the development of modern occupation education. From June 23rd to 24th, the national occupation education conference was held in Beijing. Xi Jinping made important instructions on accelerating the development of occupation education. This indicates that vocational education will enter a new period of rapid development. As the main force of vocational education, the healthy development of higher vocational education will play a good exemplary role for other vocational education. With the vigorous development of higher vocational education and the rapid growth of higher vocational students, the employment difficulty of higher vocational graduates has also become prominent, which has attracted extensive attention in society. So, how can we give full play to the advantages of higher vocational graduates, develop their strengths and avoid their weaknesses, and improve the employment rate of higher vocational students? The key to solving this problem is to improve the employability of higher vocational students (Xin, 2014)

Higher vocational students' employability is a comprehensive ability related to employment. It is a combination of a series of skills and individual characteristics. It is the ability to help vocational students get jobs smoothly, obtain and maintain jobs and promotions. Improving the employability of higher vocational students requires the joint efforts of students, schools, and enterprises. This paper expounds on how to improve the employability of higher vocational students from three aspects: students, schools, and enterprises.

\section{Methodology}

Based on the theoretical research, this study reviews and analyzes the literature from China and other countries. The data of this study are collected from the relevant journal articles written by scholars in the field of employability. Based on literature analysis, the authors summarized the authors' views.

\section{Literature Review}

Employability: Hailge \& Pollard (1998) defined employability as the ability needed to gain initial employment, maintain employment, and obtain new employment where necessary. 
As for the concept of "employability", there is no unified standard. Most scholars or institutions were explored from two aspects: the ability to obtain employment and the ability to maintain employment. Based on the above two aspects, the researcher can define employability as the knowledge, skills, attitude, and quality required for successful employment and good maintenance of employment (Di, 2015).

Xiao Yan and Wang Yan (Yan \& An, 2018) believed that the employability of students is the ability and overall quality of successful employment accumulated by the students themselves, and emphasized that employability is a common skill, and it is the ability to apply to all posts. They thought that employability is a complex system of capabilities.

\section{Current situation of Vocational College Students' employability training}

Due to the rapid expansion of the scale of higher vocational education, the school running conditions can't support the connotation construction, and the teaching quality has decreased significantly, resulting in the low social recognition of the employability of higher vocational graduates. Through further analysis, it is found that the lack of employability of higher vocational students has the following factors:

\section{From the Perspective of Students}

\section{Higher Vocational Students' Cognition of Employability and Specialty is Insufficient}

Most students in higher vocational colleges do not understand enough their major and are dissatisfied with their major. Some students have the intention to change their major, and only a few students believe that their major has a certain potential. On the understanding of the importance of Higher Vocational Students' employability, in the view of most students, students should pay attention to employment if they want to obtain jobs in the fierce employment environment. However, the vast majority of students do not understand how to improve their employability, and only a few students have participated in relevant guidance and training (Wei, 2021).

\section{Higher Vocational Students Lack the Consciousness of Career Planning}

An important reason for the low employability of higher vocational students is that they do not understand the current severe employment situation, lack of competition consciousness and crisis consciousness, have no clear career objectives and direction, and have no reasonable planning for their future career (Hui, 2020).

\section{From the Perspective of School Training}

The school learning stage is the initial stage of a career. To promote students' employability, we need to attach great importance to school education activities (Yue, Lin \& Chen, 2021).

Recognition of employability as a measure of efficacy in education outcomes escalated in the late 1990s (Lowden et al., 2011;) alongside the idea that employment and serving the economy should be a primary outcome of education (Lees \& Benza, 2015).

\section{The Unreasonable Setting of Professional Courses Leads to the Lack of Students' Comprehensive Quality}

The specialty setting and adjustment of higher vocational colleges are very backward, resulting in the dislocation of graduates' specialty structure and market supply and demand. 
According to the survey, in recent years, $70 \%$ of employers attach great importance to the comprehensive quality of employees in addition to the professional skills of employees, which indicates that the current employment market has changed from the demand mode of single technical talents to the demand mode of comprehensive all-round talents (Lu, 2016).

\section{Lack of Practical Ability Training}

Industrial work practices in vocational schools have a strategic role in preparing high quality mid-level skilled workforce following the community/industry needs. Although many research results showed the success of an internship, seen from the aspects of the process and results, there are still many gaps. According to the Directorate of Technical and Vocational Education (2008), the gap between the graduates' quality and industrial needs is still high.

At present, most higher vocational colleges attach importance to the cultivation of students' professional ability and despise the cultivation of students' practical ability. Limited by the practical training conditions of the school, students have fewer opportunities for practical operation, resulting in incompetence to the post requirements after graduation and failing to meet the employment requirements of the enterprise.

\section{Lack of Teachers}

In an environment of rapid change - technologically, economically, socially - preparing learners for the working world has become a key priority and responsibility for vocational education providers (Tertiary education commission framework for youth and transitions., 2016); 2018; Whittle et al., 2015).

Teachers in higher vocational colleges should constantly follow the requirements of the times, adapt to the new changes of professional roles, and actively improve their professional quality based on a full understanding of professional roles (Hong \& Chang, 2014). Teachers' professional ability does not fulfill the development of higher vocational education. Most teachers directly enter the school after graduation, which is not only a lack of teaching experience and skills but also a lack of practical work experience. So it is difficult to realize the training of students' employability.

\section{From an Enterprise Perspective}

\section{There is a Deviation between Enterprise Demand and Higher Vocational Education}

According to Zhang De Yi (Yi, 2020), The industrial enterprises connected by various majors in Higher Vocational Colleges show different talent level structures. Under the background of industrial transformation and upgrading, enterprises have a large demand for talents for technical posts and marketing posts, close to $80 \%$ of the total demand for talents. The demand for management posts accounts for the least. However, there is a great asymmetry between the types of graduates provided by major higher vocational colleges and the actual demand.

\section{Inconsistency between Enterprise Reality and Students' Expectations}

The information obtained by higher vocational students in school makes them full of expectations for their future work salary, treatment, and working environment. However, after understanding the actual situation of the enterprise during an internship, it is inconsistent with the expectations, resulting in a great psychological blow to many higher 
vocational graduates, leading to professional attitude, school level, not enterprising, and the professional quality shown by enterprises to students is also inconsistent with the expectations of enterprises (Liang, 2021).

\section{Strategies for improving the employability of Higher Vocational Students Improve Students' Professional Quality}

The most important factor for higher vocational students to achieve results in their essential posts is to improve their professional quality. In addition to having certain professional knowledge, we should also pay attention to the improvement of our comprehensive quality. Actively participate in community activities, professional practice, and innovation and entrepreneurship competitions after class, realize the combination of theory and practice, and improve their professional abilities such as teamwork, communication, and problemsolving. According to the requirements of this major, obtain the vocational skill level certificate and become a compound multi-functional technical talent. Collect employment information and make career planning as soon as possible to improve their employment competitiveness.

Only by constantly improving their professional quality and mastering excellent skills can school students improve their employability, working ability, and career conversion ability (Shu, 2018), we take the lead in the employment competition, take the initiative, and improve the core competitiveness, to obtain the ideal job.

\section{Starting from School, Cultivate students' Employability \\ Set up and Expand Professional Practice Courses According to Market Demand}

Higher vocational colleges should timely adjust the professional structure according to the changes of market environment, set majors around the development of regional pillar industries, and adjust the talent training objectives of the school according to the new needs of employers for talents so that the talents trained can meet the needs of social development. Because of the poor practical ability of higher vocational students, higher vocational colleges should improve the traditional teaching model in combination with the needs of enterprises and professional characteristics, increase the forms of social practice, practice and training, and the combination of work and study, let students understand the operation of enterprises and professional post standards, and cultivate students' employability to transform theory into practice (Jing, 2014).

\section{Establish a Perfect Employment Guidance Mechanism and Cultivate Students' Entrepreneurial Consciousness}

Higher vocational colleges should carry out employment guidance, strengthen employment services, and run employment guidance through their usual teaching activities. Facing the increasingly specialized employment market, schools should keep up with the pace of the development of the times, give scientific guidance to students' employment activities, and promote the employability of higher vocational students to be improved. $(\mathrm{Xu}, 2021)$

Now many higher vocational colleges have carried out courses related to students' entrepreneurship to cultivate students' entrepreneurial awareness, and then gradually cultivate students' entrepreneurial ability. Entrepreneurship is another form of employment. Higher vocational colleges should start from the characteristics of students, carry out various 
forms of entrepreneurship education and targeted entrepreneurship training, cultivate students' pragmatic entrepreneurial concept and entrepreneurial ability, and establish special entrepreneurship guidance institutions to provide students with a series of services such as policy consultation, project feasibility analysis and Entrepreneurship guidance (Lu,2016).

\section{Improving Teachers' Quality}

Broadly, teachers were observed by researchers explicitly establishing a positive and productive learning environment, with expectations that align with industry standards. This was also evident in a classroom culture that celebrates learner progress, clarify gaps, and provides feedback and feed-forward guidance (Fraser, Duignan, Stewart \& Rodrigues, 2019).

Higher vocational colleges should broaden teachers' knowledge, arrange professional teachers to practice in the front line of enterprises, master the most advanced professional technology of enterprises, and understand the actual needs of enterprises for students' post ability. Make teachers personally experience the needs of enterprises for applied talents, bring corporate culture and talent needs into the classroom, combine theoretical knowledge, make education and teaching more attractive, make students exposed to advanced corporate ideas and excellent corporate culture in the classroom, and imperceptibly improve students' employability (Zhen, 2017).

\section{Starting from Enterprises, Improve the Employability of Higher Vocational Students Enterprises Actively Participate in the Curriculum Construction of Higher Vocational Colleges}

In May 2014, the State Council issued 《The Decision of the State Council on Accelerating the Development of Modern Vocational Education》, which proposed to "guide social forces to participate in the teaching process and jointly develop educational resources such as courses and teaching materials". Enterprises participate in the setting and design of courses, including the determination of talent training objectives, the setting of curriculum system, the establishment of the curriculum evaluation system, and the guidance of practical teaching, to make the combination module of higher vocational courses more reasonable, make the selection of teaching content more in line with the development trend of the industry, and make the talent training objectives of higher vocational education more in line with the needs of the society, Cultivate more qualified and high-quality applied talents, and the enterprise becomes the direct beneficiary.

\section{Deepen School-enterprise Cooperation and Jointly Build a Practice Base}

A practical teaching base is a link between higher vocational college students and society. It is an important place to cultivate students' professional core competence, basic practical skills, and professional adaptability. By strengthening the cooperation between schools and enterprises, enterprises can be used as off-campus training bases for higher vocational colleges. To provide a complete real working environment for higher vocational students, students can directly experience the requirements of actual jobs, continuously improve professional skills in practice, and improve the level of social adaptabilities such as unity and cooperation consciousness. Realize the seamless connection between the professional learning of higher vocational students and the employment needs of employment units, and ensure the employment quality of higher vocational graduates. Through school-enterprise cooperation, improve the teaching content of the school, realize targeted curriculum 
learning, reduce the gap between professional learning and practical application, and enable students to successfully meet the job requirements after graduation. (Ding \& Xu, 2021)

\section{Conclusion}

As the main force of future social development, higher vocational graduates need to improve their employability. This paper analyzed the current situation of the cultivation of Higher Vocational Students' employability from many aspects and makes an in-depth analysis on the problems surrounding the current higher vocational students' employability. To prevent and solve the problem of employment ability training in Higher Vocational Colleges from the root. The improvement of students' employability can be realized through a variety of strategies, which provide new ideas and new perspectives for the improvement of Higher Vocational Students' employability.

First of all, students need to change their minds, to be better understand their majors, improve their comprehensive ability, start career planning as soon as possible and improve their employment competitiveness. Secondly, higher vocational colleges should constantly reform the professional curriculum, increase the teaching content of practice and employment, improve teachers' practical ability, and increase entrepreneurship counseling, so that students can have access to good vocational education in the whole stage of higher vocational education. Finally, enterprises and schools cooperate deeply, build a practice base, and increase the participation of enterprises in the cultivation of students' employability utilizing school-enterprise cooperation, to help optimize the overall employability of students in higher vocational colleges. To sum up, under the new form of employment, higher vocational college students, schools, and enterprises need to work together to shoulder their respective responsibilities and obligations and improve the employability of higher vocational students in an all-round way, to solve the problem of difficult employment of higher vocational graduates.

However, the implication of this study can help graduate to improve their employability at higher vocational institutions and to solve the employment problem of higher vocational students. As well as, will help vocational institutions to develop their course Curriculum to fulfill the graduates' future market.

\section{References}

Ding, J. F., \& Xu, Y. Y. (2021). Measures to improve the employability of higher vocational students from the perspective of school-enterprise cooperation. Management and Standardization, 11.

Di, L. W. (2015). Study on the matching between College Students' employability and social needs -- a case study of Beijing University of traditional Chinese Medicine. Beijing University of Chinese Medicine.

Di, L. W. (2015). Study on the matching between College Students' employability and social needs -- a case study of Beijing University of Traditional Chinese Medicine. Published master dissertation. Beijing University of Chinese Medicine.

Feng, D. J., \& Yan, X. Y.(2021). Measures to improve the employability of higher vocational students from the perspective of school-enterprise cooperation. Management and Standardization, 11.

Fitriyanto, M. N., \& Pardjono. (2019). Factors Affecting The Employability skills Of Vocational Studnets majoring Mechanical Engineering. Jurnal Pendidikan Vokasi, 9(2), 132-140. 
Fraser, C., Duignan, G., Stewart, D., \& Rodrigues, A. (2019). Overt and covert: Strategies for building employability skills of vocational education graduates. Journal of Teaching and Learning for Graduate Employability, 10(1), 157-172.

Hillage, J., and Pollard, E. (1998) Employability: Developing a Framework for Policy Analysis. Department for Education and Employment, London.

Hong, W. X., \& Chang, D. J. (2014). Role Positioning and Occupation Accomplishment of Teachers in Higher Vocational Schools. Research on Higher Engineering Education, 4.

Hui, Y. X. (2020). Research on the strategy of improving the employability of higher vocational students from the perspective of psychological capital. Journal of Hebei Software Institute, 22(4)

Jing, L. (2014). Strategies for the Improvement of Vocational College Students Employability. Journal of Changjiang Engineering Vocational College,31(4).

Khalid , N., Abd Hamid, A., Sailin, R., Othman, N., Awang, A. H., \& Nor, M. F. (2014). Importance of Soft Skills for Industrial Training Program: Employers' Perspective. Asian Journal of Social Sciences \& Humanities, 3(4).

Lu, H. (2016). Investigation on the current situation of Higher Vocational Students' employability and Research on its promotion strategy. Journal of Jiamusi Vocational College, (1).

Lee, S., \& Benza, R. (2015). Teaching innovation skills: Application of design thinking in a graduate marketing course. Business Education Innovation Journal, 7, 43-51.

Liang, N. (2021). How to improve the employability of higher vocational students in Enterprises? Industrial \& Science Tribune, 20(11)

Lowden, K., Hall, S., Elliot, D., \& Lewin, J. (2011). Employers' perceptions of the employability skills of new graduates. London, UK, University of Glasgow SCRE Centre and Edge Foundation.

Shu, C. K. (2018). On the influencing factors and promotion path of College Students' employability. The Science Education Article Collects, 32,139-140.

Whittle, J., Bodkin-Allen, S., \& Hoffman, J. (2015). The ITP sector collaboration practices report, (April). Retrieved from https://www.sit.ac.nz/Portals/0/upload/documents/ research/ Collaboration Report .

Wei, X. (2021). Exploration on improving the employability of Higher Vocational Students under the concept of career planning. Employment and Security, 9, 68-69.

Xin, L. H. (2014). Strategy Research On Improving The employability of higher Vocational Students. Science and Technology Innovation Herald, 34.

Xin, L. H. (2014). Strategy research on improving the employability of higher vocational students, Science and Technology Innovation Herald, 34.

$\mathrm{Xu}, \mathrm{W}$. (2021). Exploration on improving the employability of Higher Vocational Students under the concept of career planning. Employment and security Journal, (09).

Yue, C. S., Lin, X. X., \& Chen, G. R. (2021). Exploration on Ideological and political innovation of career planning course in Higher Vocational Colleges. Journal of Beijing Institute of Technology, 01, 108-110.

Yan, X., \& Nan, W. Y. (2018). An Analysis of the Dimensional Structure of College Students' Employability. Journal of Xi'an Shiyou University (Social Science Edition), 1, 3-8.

Yi, Z. D. (2020). Student management mechanism in Higher Vocational Colleges from the perspective of employability training. Research on Continuing Education, 37(5), 30-34.

Zhen, W. L. (2017). On the main ways to improve college students' employability. Modern Vocational Education, 8,155. 
(2008). Directorate of Technical and Vocational Education. Pelaksanaan prakerin. Jakarta: Directorate of Technical and Vocational Education, Department of National Education.

........(2014). The Decision of the State Council on Accelerating the Development of Modern Vocational Education. Retrieved from http://www.jyb.cn/zyjy/zyjyxw/ 201406/t20140622_587161 .html,2014-06-22.

........(2016). Tertiary education commission framework for youth and transitions. Tertiary Education Commission.

........(2018). Tertiary education commission framework for youth and transitions. Tertiary Education Commission.

........(2020). Chinese 3-year Vocational College Graduates 'Employment Annual Report. Mycos. 